\title{
Forces Driving Maquiladoras Along The Border Of Mexico And The United States: A Short Communication
}

Allan Beck, University of Phoenix, USA

\begin{abstract}
Mexico's maquiladora industry is as important to the national economy as oil production and tourism for direct foreign investment and is a force that Mexico and partners need to understand and cultivate. Many internal and external factors affect the performance of maquiladora plants and they are heavily influenced by the U.S. economy. Long histories and blending of cultures have created a border region that is interrelated and dependent in both directions across the border. A review of the literature suggests many approaches to make maquiladoras competitive in global commerce. Getting the most out of maquiladoras may go beyond systems and processes because the best results may come from understanding and cultivating the rich culture the region holds as the critical resource in building teams and relationships. World class manufacturing takes systems and processes but does not forget the culture. A combination of nurturing people and nurturing a proximity strategy may be the most effective approach to sustainability.
\end{abstract}

Keywords: Mexico; Operations Management; Maquiladoras; Manufacturing Sustainability

\section{INTRODUCTION}

\section{Forces Driving Maquiladoras}

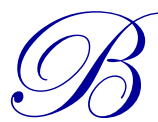

y 1965, the Bracero, or guest worker, program ended in the United States and the Border Industrialization Program was established by Mexico as a means of replacing lost jobs by attracting investments and creating opportunities by setting up a process that allowed temporary import duty free and only taxing the value added portion of transactions (Eldenburg, Roman \& Teruya, 2007). The Border Industrialization Program laid the groundwork for the maquiladora program, which was legally established in 1971. Many U.S. companies started manufacturing on the northern border of Mexico because the arrangement allowed companies to take advantage of the lower Mexican wage rate.

The arrangement worked well and manufacturing became an important part of the Mexican economy. The maquiladoras represent a good source of foreign direct investment and a good source of employment and earnings for many Mexican citizens (Truett \& Truett, 2007). Recent downturns in maquiladora employment has hurt the economy because the continual growth experienced until 2000 was creating the required one million new jobs a year to keep up with new young worker additions from population growth (Walkkirch, Nunnenkamp, \& Alatorre Bremont, 2009). The border area also had an abundance of workers as it attracted laborers from well within the interior (Mendoza, 2010).

\section{LITERATURE REVIEW}

Maquiladora factories hit a peak in 2000, but from 2000 to 2003 they lost 300,000 jobs and the low-wage model that had been so successful for past business was in peril (Sargent \& Matthews, 2009). One of the largest competitors was China, who had lower wages and the benefit of a high-tech strategy, which added a level of competition to both the high-tech and low-tech ends of manufacturing (Sargent \& Matthews, 2009). The loss of 
jobs and the lack of an effective strategy to counter the loss of business and jobs to Asia should have sent an alarm to Mexico.

The lack of a strategy and the poor education system in Mexico left the country defenseless to the competition. Existing maquiladoras struggled to retain business and by cutting costs, they were able to retain a share of the manufacturing opportunities. In the late 2000s another challenge to manufacturing and other sectors of the economy occurred when security became an issue with infighting from the competitive cartels (del Bosque, 2009). The drug cartels and the open fighting in the streets of the northern cities eliminated some travel across borders for fear of kidnappings and other violence (del Bosque, 2009). One of the most impactful changes the cartel activity has created is a talent-shortage of high-skilled individuals in the northern border cities (Wilson, 2009, p. 543). Violence is driving the high-skilled individuals into the interior away from the intense violence seen in northern border cities (Wilson, 2009, p. 543).

The North American Free Trade Agreement, ratified in 1994, established a trade agreement between Mexico, Canada, and the United States. From 1993 to 2000, maquiladora exports rose from $\$ 21.9$ billion to $\$ 79.5$ billion (Mendoza, 2010). In 2001, maquiladora exports dropped to $\$ 76.9$ billion and have not seen the growth experienced in the previous decade since (Mendoza, 2010). Although export activity is one of the key features of maquiladora success, the accelerated expansion and growth experienced by Mexican maquiladoras has shifted to China in recent years (Mendoza, 2010).

Before the North American Free Trade Agreement was ratified, proponents argued that the maquiladora program would enhance job creation, expand the tax base and wages, generate foreign direct investment, and allow technology transfer to take place (Fiscal incentives, 2010). The individuals against the agreement argued that the jobs created were low-quality and poorly paid, health and safety standards were largely ignored, gender bias occurred frequently, and maquiladoras fragmented the rest of the economy because of the ties to the U. S. business cycle (Fiscal incentives, 2010). Significant data are available after many years of the North American Free Trade Agreement and the results are mixed. Maquiladora employment under the North American Free Trade Agreement is not a predictor of any standard of living and maquiladora employment seems to have a negative effect on education, a small negative effect on housing, and real wages have decreased when compared to the cost of living (Fiscal incentives, 2010).

The North American Free Trade Agreement presented some economic opportunities for Mexico, but the advantages have not been great enough to offset the increasing impact of Chinese exports in the United States (Mendoza, 2010). The reductions in tariffs and non-tariff barriers implemented through the North American Free Trade Agreement have eroded any advantage the maquiladoras had prior to the ratification of the agreement (Waldkirch, et al., 2009). The only real increase was realized in the upper wage groups, particularly for workers highly educated (Airola, 2008).

\section{DISCUSSION}

A broad range of factors affect performance in Mexico's maquiladoras. Internal factors may include human resources, empowerment, training, teamwork, management empowerment, management training, and environmental performance (Daily \& Bishop, 2012). Both managers and employees can be effective in creating the necessary changes to improve performance with the proper level of training and empowerment (Daily \& Bishop, 2012).

Internally, Mexico has been able to evolve from a largely cheap labor and low value-added formula to a more complex provider, which offers just-in-time, continuous improvement, job safety, environmental performance, and a reliable source of supply (Carrillo \& Zarate, 2009). In other words, Mexico has been able to train its workers and implement some of the best practices in the manufacturing sector (Carrillo \& Zarate, 2009). Another important factor that affects global sourcing is product quality.

A quality system with managerial support and employee involvement are important to original equipment manufacturers because the brand name is on the product regardless of the producing site, and a lack of quality can 
affect the reputation, image, and ability to grow the business (Dowlatshahi, 2011). Maquiladora strategies need to include an effective quality program with ISO certification or other requirements as dictated by the industry served (Dowlatshahi, 2011). International Standards Organization certification shows a dedication to product quality and a structured documented standard that is recognized throughout the world for delivering customer satisfaction (Dowlatshahi, 2011). International Standards Organization or other quality certifications can lead to supplier relationships that can lead to new business opportunities (Dowlatshahi, 2011).

A large influence on the external forces affecting Mexican maquiladoras has been the Chinese economy (Mendoza, 2010). Many U.S. companies have shifted the outsourcing decisions toward China, which offers both a more technical base and a lower wage structure (Mendoza, 2010). The trend has impacted maquiladora growth in a negative direction (Mendoza, 2010). Mexico has yet to find a counter-measure to reduce the market penetration of Chinese exports, and NAFTA advantages have not been sufficient to give Mexico a trade advantage (Mendoza, 2010). China is threatening the cross-border interdependence as technology has allowed China to increase the share of products entering the United States (Ma \& Wooster, 2009).

Another large influence on maquiladora production rates is the relationship between maquiladoras and the interdependence on the United States economy (Ma \& Wooster, 2009). The external contraction is due, in part, to a decline in the economy of the United States and the increase in the Mexican wage rate (Ma \& Wooster, 2009). Border trade creates jobs in border cities and demand for jobs, real estate, retail, and other cross-border commerce (Ma \& Wooster, 2009).

Mexico and the maquiladora industry are at a crossroad of where the path should be moving forward. There is argument for many paths, including high-tech, proximity, process improvement, and modernization (Carrillo \& Zarate, 2009). Manufacturing is an important section of the Mexican economy and caution must be used to preserve the sector served by maquiladoras. Proximity to the United States should be maximized as a competitive advantage to preserve a significant part of the United States market for Mexico.

Even though China and other low-cost producers have taken away a significant share of the maquiladora United States import market, there may still be reason to believe that maquiladoras will remain an important source of supply for the United States (Sargent \& Matthews, 2007). Even though the Mexican model is no longer the lowcost alternative, many advantages still make Mexico viable because the wages are still significantly lower than in the U.S. and the advantage that physical closeness to the United States offers many sourcing advantages (Sargent \& Matthews, 2007). By adopting a proximity, or close-to-market strategy, low shipping costs, faster delivery, developing niche products and other models, including low volume with a high mix, can sustain the maquiladora industry far into the future (Sargent \& Matthews, 2007).

\section{CONCLUDING COMMENTS}

The backbone of the Mexican manufacturing industry is the maquiladora system and recognizing weaknesses allows leaders to shore up resources to reinforce the industry. Manufacturing has surpassed tourism and petroleum products to be the number one source of foreign direct investment for Mexico (Zerlentes, Hewings, \& Weiler, 2009). Many municipalities already waive the maquiladora fees under NAFTA as cities want to create reasons for sustainability of the important economic factor (Zerlentes, et al., 2009). Border cities are particularly sensitive to the importance of maquiladoras to the lives of citizenry.

Perhaps one way to meet worker needs and retain employees in an industry known for high turnover is to turn to professor Hofstede's cultural dimensions. Mexican workers have a common set of values dictated by the culture that affects attitude and behavior (Najera, 2008). For example, a supervisor is an important part of a Mexican maquiladora worker's life, and expectations are that the supervisor will have the best interests of workers as a key objective (Najera, 2008). Small celebrations and signs of appreciation mean a lot to maquiladora workers (Najera, 2008). Friends among co-workers are important and activities that allow workers to gather outside of work should be held regularly (Najera, 2008). 
The activities and signs of appreciation that have little cost are worth pursuing. The list of activities that supervisors and maquiladora operators can do may not cost much, but may have the greatest impact on building a team and retaining employees. Once the foundation is laid, keep nurturing the process and be consistent with employee interaction. Balancing the proximity strategy and taking care of its workers is the key to sustaining Mexico's maquiladoras.

\section{AUTHOR INFORMATION}

Dr. Allan Beck is an international business and maquiladora specialist with over 20 years of experience as an employee or a supplier to maquiladora facilities along the U.S. and Mexico border. He has held many management positions in his career, including supervisor, production manager, engineering manager, operations manager, plant manager, division operations manager, general manager, and vice president. He is teaching undergraduate and graduate level management classes at the University of Phoenix and The University of Texas - Pan American. Dr. Beck can be reached at e-mail: mcbek@email.phoenix.edu

\section{REFERENCES}

1. Airola, J. (2008). A regional analysis of the impact of trade and foreign direct investment on wages in Mexico, 1984-2000. Review of Development Economics, 12(2), 276-290. doi:10.1111/j.14679361.2008.00428.x.

2. Daily, B. F., Bishop, J. W., \& Massoud, J. A. (2012). The role of training and empowerment in environmental performance: A study of the Mexican maquiladora industry. International Journal of Operations \& Production Management, 32(5), 631-647. doi:10.1108/01443571211226524

3. del Bosque, M. (2009). Hyping the new media buzzword: 'Spillover' on the border. NACLA Report on the Americas, 42(4), 46-48. Retrieved from EBSCOhost.

4. Dowlatshahi, S. (2011). An empirical study of the ISO 9000 certification in global supply chain of maquiladoras. International Journal of Production Research, 49(1), 215-234. doi:10.1080/00207543.2010.508949.

5. Carrillo, J., \& Zarate, R. (2009). The Evolution of Maquiladora Best Practices: 1965-2008. Journal Of Business Ethics, 88335-348. doi:10.1007/s10551-009-0285-8.

6. Eldenburg, L., Roman, F., \& Teruya, J. (2007). An analysis of the effects of maquiladora production and performance. Journal of Accounting, Auditing \& Finance, 22(3), 423-447. Retrieved from Business Source Complete database.

7. Fiscal incentives, maquiladoras, and local standard of living in Mexico before and after NAFTA. (2010). Public Finance \& Management, 10(3), 442-481. Retrieved from EBSCOhost.

8. Ma, A. C., \& Wooster, R. B. (2009). The effects of U.S.-China trade on employment and wages in the U.S.-Mexico border region. Contemporary Economic Policy, 27(3), 335-348. doi:10.1111/j.14657287.2008.00140.x.

9. Mendoza, J. (2010). The effect of the Chinese economy on Mexican maquiladora employment. International Trade Journal, 24(1), 52-83. doi:10.1080/08853900903442921.

10. Najera, M. (2008). Managing Mexican workers: Implications of Hofstede's Cultural Dimensions. Journal of International Business Research, 7(2), 107-126. Retrieved from EBSCOhost.

11. Sargent, J., \& Matthews, L. (2009). China versus Mexico in the Global EPZ industry: Maquiladoras, FDI quality, and plant mortality. World Development, 37(6), 1069-1082. doi:10.1016/j.worlddev.2008.10.002.

12. Truett, L. J., \& Truett, D. B. (2007). NAFTA and the maquiladoras: Boon or bane? Contemporary Economic Policy, 25(3), 374-385. doi:10.1111/j.1465-7287.2006.00043.x.

13. Walkkirch, A., Nunnenkamp, P., \& Alatorre Bremont, J. (2009). Employment effects of FDI in Mexico's non-maquiladora manufacturing. Journal of Development Studies, 45(7), 1165-1183. doi:10.1080/00220380902952340.

14. Wilson, R. (2009). Historical Encyclopedia of American Business. (Rev. ed.). Pasadena, CA: Salem Press.

15. Zerlentes, B., Hewings, G. D., \& Weiler, S. (2009). Modeling Production Externalities in the Maquila Industry. Ecological Economics, 68(3), 822-835. doi:http://dx.doi.org/10.1016/j.ecolecon.2008.06.020. 